\section{Priming Sweet Corn Seed to Improve Emergence Under Cool Conditions}

\author{
Glen A. Murray ${ }^{1}$ \\ Department of Plant, Soil, and Entomological Sciences, University of \\ Idaho, Moscow, ID 83843
}

Additional index words. Zea mays, polyethylene glycol, osmoconditioning, germination

Corn inbreds planted when soil is $10 \mathrm{C}$ and lower are often injured by cold water imbibitional stress (Cohn and Obendorf, 1978). Bodsworth and Bewley (1981) found that polyethylene glycol (PEG) 6000 promoted seed germination of two field corn cultivars when germinated at $10 \mathrm{C}$. The objective of the current study was to evaluate PEG 8000 for improving emergence of two sh2 sweet corn hybrids.

Six seeds of sweet corn $s h 2$ hybrids ('Crisp 'N Sweet' and 'How Sweet It Is'; Crookham Seed Co.) were placed in 9-cm-diameter petri dishes containing $15 \mathrm{ml}$ of PEG 8000 absorbed into two sheets of Whatman \#1 filter paper. Seeds were in excellent contact with a thin layer of PEG on the surface of saturated filter paper. Concentrations used were 100,200, and $300 \mathrm{~g} \mathrm{PEG/liter} \mathrm{distilled} \mathrm{water}$ $(-0.16,-0.56,-1.14 \mathrm{mPa}$, respectively) (Michel, 1983). Seeds were primed at 15C for either 4, 3, 2, or 1 days, such that priming was completed for all seeds on the same day. Control seeds received no treatment.

Excess PEG was rinsed off with distilled water. Control and treated seeds were planted immediately after completion of the 4-day priming treatment. Six seeds of each cultivar were placed on the surface of unsterilized potting mixture of 1 vermiculite $: 1$ sand :1 pedite :1 silt loam soil (by volume) in 0.8 liter round pots and covered to a depth of $2.5 \mathrm{~cm}$. There were two pots per treatment for each cultivar. Pots were covered with plastic wrap to prevent moisture loss and placed in a growth chamber at $10 \mathrm{C}$ for 12

Received for publication 1 Mar. 1989. Idaho Agricultural Experiment Station Research Paper no. 88763. The cost of publishing this paper was defrayed in part by the payment of page charges. Under postal regulations, this paper therefore must be hereby marked advertisement solely to indicate this fact.

'Professor of Plant Science. days to create imbibitional stress. Thereafter, the chamber was held at $15 \mathrm{C}$ to test emergence, which was scored daily. $\mathrm{Cu}-$ mulative emergence data were analyzed after an arcsin transformation. Actual data are used in the figures, but significance is based on transformed data.

Priming significantly improved seedling emergence rate; final emergence was similar to that of unprimed seed (Fig. 1). Reduced emergence from control seeds was likely due to cold water imbibitional damage (Cohn and Obendorf, 1978), as no evidence of seedling disease was found.

Hybrids responded differently to priming duration and PEG concentration (Fig. 2). Optimal emergence of 'How Sweet It Is' resulted from 1 day of priming with $100 \mathrm{~g}$ PEG/liter. In contrast, optimal emergence of 'Crisp 'N Sweet' resulted from either 2 or 3 days of PEG treatment (100 or 200 g.liter ${ }^{-1}$, respectively). These data showed that priming enhanced sweet corn ( $\operatorname{sh} 2)$ seedling emergence under cool conditions and agrees with results found by Bodsworth and Bewley (1981) with field corn. Optimum priming duration and osmotic potential for sh2 cultivars used in our study varied from 1 to 2 days and $-0.16 \mathrm{mPa}$ to $-0.56 \mathrm{mPa}(100$ to $200 \mathrm{~g} \mathrm{PEG/liter),} \mathrm{respectively,} \mathrm{while} \mathrm{the}$ optimal condition for field corn was 6 days at $1.0 \mathrm{mPa}$ (Bodsworth and Bewley, 1981). Emergence response to presowing hydration was also cultivar-dependent with high sugar sweet corn (Bennett and Waters, 1987). These comparisons with sweet corn show that optimal priming duration and PEG concentration will also likely vary with cultivar.

\section{Literature Cited}

Bennett, M.A. and L. Waters, Jr. 1987. Germination and emergence of high sugar sweet com improved by presowing hydration of seed. HortScience 22:236-238.

Bodsworth, S. and J.D. Bewley. 1981. Osmotic priming of seeds of crop species with polyeth- ylene glycol as a means of enhancing early and synchronous germination at cool temperatures. Can. J. Bet. 59:672-676.

Cohn, M.A. and R.L. Obendorf. 1978. Occurrence of a stelar lesion during imbibitional chilling of Zea mays L. Amer. J. Bet. 65:50-56.

Michel, B.E. 1983. Evaluation of the water potential of solutions of polyethylene glycol 8000 both in the absence and presence of other solutes. Plant Physiol. 72: 66-70.

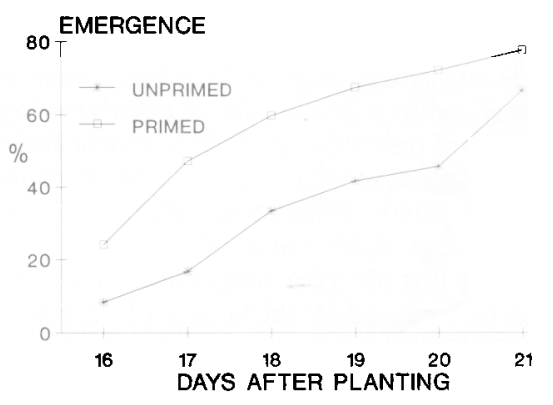

Fig. 1. Seedling emergence at $15 \mathrm{C}$ from primed and unprimed sweet corn seed following 12 days of imbibition at 10C. Responses averaged over

from primed seed was significantly different than emergence from unprimed seed on each day but 16 and $21(P=0.01$, arcsin transformation).
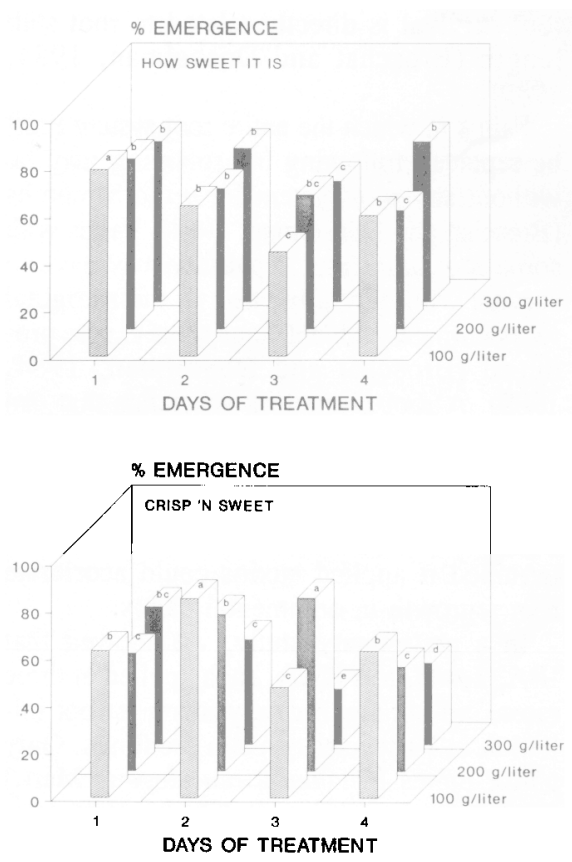

Fig. 2. Interaction of PEG concentration, priming duration, and cultivar on seedling emergence of 'How Sweet It Is' (top) and 'Crisp 'N Sweet' (bottom) sweet corn. 